American Journal of Agricultural and Biological Sciences 5 (1): 77-83, 2010

ISSN 1557-4989

(C) 2010 Science Publications

\title{
Factors Influencing the Development of Entrepreneurial Education in Iran's Applied-Scientific Educational Centers for Agriculture
}

\author{
${ }^{1}$ Baharak. Azizi, ${ }^{1}$ Jamal F. Hosseini, ${ }^{2}$ Mahmood. Hosseini and ${ }^{1}$ Mehdi. Mirdamadi \\ ${ }^{1}$ Science and Research Branch, Department of Agricultural Extension and Education, \\ Islamic Azad University, Iran \\ ${ }^{2}$ Department of Agricultural Extension and Education, Tehran University, Iran
}

\begin{abstract}
Problem statement: An understanding of factors influencing entrepreneurial education in Iran's applied-scientific educational centers for agriculture is crucial for creating the new opportunities for students and encouraging them to involve in entrepreneurial activity. The purpose of this study was twofold. First, it determined the key factors that influence entrepreneurial education in Iran's appliedscientific educational centers for agriculture. Second, the study examined relationship of these factors with developing entrepreneurial education. Approach: The research in terms of nature is a kind of quantitative research and in terms of goal is applied research, in terms of controlling the variables is descriptive and correlation kind, which has been carried out in a survey way. Statistical population of the study consisted of 19255 students for applied-scientific education in agriculture in Iran. Based on the classification of the Ministry of Agriculture which has divided these centers into five regions, sample taking has been conducted using stratified proportionate random sampling technique. Sample size for the students is 355 people using Cochran formula. Considering the entire size of the sample, some 291 questionnaires have been returned. Results: The results of the ordinal factor analysis showed the classification of the factors into five latent variables. The variables were classified into managerial, economical, social, technical and regulatory. The basic idea of factor analysis was to found a set of latent variables that contain the same information. The classic factor analysis assumed that, both observed and the latent variables were continuous variables. But, in practice, the observed variables were often ordinal. Spearman coefficient showed that there was relationship between economical, social, technical, regulatory and managerial factors and perception of students about entrepreneurial education. Conclusion: Entrepreneurial education had a tremendous potential to help in the employment status of students in Iran's applied-scientific educational centers for agriculture. These centers had the opportunity to play a major role in the development of entrepreneurial education. The development of entrepreneurial education results in creating more jobs and employment sustainability could be achieved over time. Therefore, certain special factors in developing entrepreneurial education among students in these centers should be identified and need to be carefully examined. Innovative strategies need to be developed that cater specifically the entrepreneurship educational needs of students. Applied-scientific educational centers for agriculture in Iran need to provide practical training in entrepreneurship to their students, to make them more aware of the benefits of entrepreneurship and to address the factors that impact on developing entrepreneurial education in the centers.
\end{abstract}

Key words: Entrepreneurship, entrepreneurial education, applied-scientific education

\section{INTRODUCTION}

With regard to population growth during 1979-1989 and that wave reaching to the first decade of 21 st century, lack of progress in agricultural economy, immethodical expansion of agricultural higher education, excessive number of agricultural graduates, government policies to downsize its structure, inability of agricultural private sector to employ the graduates due to traditional structure of production and livelihood exploiting system, Iran has faced an intensive crisis of unemployment for agricultural graduates in 2000s. At present based on available authorized statistics it is estimated that there are 42,500 unemployed agricultural graduates. Iranian agricultural higher education system has to find a comprehensive solution for the employment of graduates

Corresponding Author: Baharak. Azizi, Science and Research Branch, Department of Agricultural Extension and Education, Islamic Azad University, Iran 
in self-employment sector (The Agriculture and Natural Resources Engineering System Organization, 2007).

Entrepreneurial education can play a significant role in changing views of students towards selfemployment and through education on necessary skills to manage a business has prepared them for selfemployment labor market (Nelson, 1986).

Oversupply of graduate manpower in agricultural sector, unemployment growth in their community, lack of response or positive feedbacks to the efforts made in recent decade to find a solution for unemployment problem of graduates on one side and on the other hand the necessity to move to competitive agriculture based on market caused to pay more and more attention to entrepreneurship as a fundamental issue. Proposing new ideas based on the role of entrepreneurship in increasing job opportunities, competitiveness, improvement in manpower productivity, technology development, wealth generating and social welfare level and also existence of strong relation between entrepreneurial development and economic growth of the countries have all resulted in a serious consideration of entrepreneurship in new economic theories and have been regarded as a provocative engine in economicalsocial growth and development of countries (Audretsch, 2002; Zoltan, 2006). This issue which has been noticed in agricultural economy and development of entrepreneurship is one of the necessities of agricultural development (Smit, 2004).

Such situation has brought about an increasing demand in agricultural entrepreneurship education in recent years and has been emphasized by researchers and government authorities in different countries (McElwee, 2005).

As a result in agricultural sector the entrepreneurial education has been turned to a serious necessity and the governments must compile strategic plans for entrepreneurial education in agricultural sector in order to upgrade the individual's capabilities for the entrepreneurship (Smit, 2004). Indeed, the entrepreneurship is a key element in production and employment increase, a solution to fight against the unemployment crisis, a response to community diverse demands; therefore, it is considered as one of the important fundamental aspects in agricultural development plans (Higgins and Morgan, 2000; Sherief, 2005; Smit, 2004).

With a look at the background of education in agricultural sector in Iran it can be observed that the amount of investment and paying attention to this issue from different dimensions has never been at expected education dignity level or proportionate to indexes and employment criteria. Furthermore, available resources, expansion of this sector in term of frequency, employees and beneficiaries of this sector ( 3.5 million Individuals as beneficiaries) were not applicable to the country's demands (Institute of Applied-Scientific Educations, 2002).

Although considerable efforts of universities and higher education agricultural centers in educating and training of specialist human resources should not be ignored, concentrating on learning theoretical knowledge (Know-How) instead of applied-scientific knowledge, inattention to innovation and initiative abilities of learners, disproportionate text books syllabuses with labor market requirements, inefficient efforts in teaching practical courses, insufficient experienced and skilled lecturers for teaching the latter courses and inefficient graduates from universities and higher education centers in labor market, especially in agricultural section, are of the major difficulties in this system (Hajimirrahimi, 1999).

According to UNESCO (1997) universities educations develop scientific theories while appliedscientific education is there to carry out the theories. Actually, these two types of education are parallel and supplementary. On one side applied-scientific educations can reduce the risk and the danger of youth unemployment dramatic increase and on the other, decrease full time unemployment of low skilled and incapable individuals (Varma, 2000).

In a research, Zamani (2001) has emphasized on unemployment of most of agricultural graduates, thus recommending what follows, as the results of his study, to improve the educational system of this sector:

- Expanding the practical courses

- More close cooperation and relation between universities with executive departments and the farmers

- Establishing self-employment and entrepreneurship mentality in students

- Emphasis on short training courses during the academic year

In another research on situation of appliedscientific students of the Ministry of Agriculture Heydari (2002) has emphasized on the following comments:

- New outlook in syllabus planning for each course according to entrepreneurship standards and community needs

- Emphasis of educational contents on scientific and practical educations 
Fayzabadi and Khoynejad (2002) in their research on employment situation of applied-scientific graduates of Agriculture Ministry suggested the following recommendations:

- Improving scientific level of the professors and lecturers

- Establishing employment agency in complexes

- Increasing scientific and applied skills in courses

- More conformity of the majors with labor market needs

Mirzaee (2002) in his study on employment situation of the applied-scientific educations graduates has obtained the following results:

- Student admission has to be done in compliance with the real requirement of labor market

- Factors such as social relation, capital, finance and more practical experience in the profession are among the most effective for employment based on graduates view points

- Revise text books syllabuses according to labor market needs, increasing training centers and eliminating professional skill weakness of students, labor cultural development, establishing a secure environment for agricultural investment and guaranteeing the interest of the investment

- Increasing practical skills in courses, improvement of scientific level of professors and lecturers, emphasizing on guidance and job advisory services to students during the course and establishing employment agencies in agricultural appliedscientific centers

Nouroozzadeh and Mehrabiyeganeh (2006) in their studies recommended that entrepreneurship development in agricultural applied-scientific higher education centers is one the efficient methods for increasing human resources productivity in agriculture sector.

According to opinions of public and private contractors and supervisors, the productivity of appliedscientific graduates is much more comparing to other educational systems (Lankard, 1994).

In an essay titled as university and entrepreneurial development Ussman (1998) expresses that establishing a firm is a fundamental element in economic prosperity of both developed and developing economies which depends on two factors: Public atmosphere and individual atmosphere.
Landkinen (2000) in his research emphasized that applied-scientific education could be considered as an investment for human resources qualitative improvement, because such educations result in knowledge and skill in production procedure in the direction of social and economical development.

Australian Vocational Education and Training Statistics (ERIC, 2001) has revealed that employers are completely satisfied about skills of applied-scientific educations of graduates and believed that appliedscientific educations can compensate their expenses through increasing the productivity of staff.

The findings of another study, carried out at US Cornell University toward wide entrepreneurial education at university, alternative models and current trends indicate:

- The trend toward entrepreneurial education is strong

- Our conceptual framework clarifies the different pathways for creating a university wide approach toward entrepreneurship

- While the radiant model (entrepreneurship out of university) is extremely appealing to students, parents and alumni, the magnet model (entrepreneurship inside university) is easier to administer and present in various methods

- While the magnet model is simpler to implement, it may lead to conflicts in a long run because the benefits and facilities may not be distributed equally among the university students (Streeter et al., 2002)

Kuratko (2003) in a study entitled emergence of entrepreneurial education: Development, trends and challenges, says that the entrepreneurship has emerged and developed over the recent two decades and its recent growth in curricula and programs dedicated to entrepreneurship has been very considerable. The number of faculties and universities which deliver curricula in connection to entrepreneurship has surged to over 1600 in 2005 in comparison to few programs in 1970's. This huge development has resulted in some academic legislative challenges for entrepreneurship that this article has focused on these trends and challenges of entrepreneurial education in the universities in the 21 st century.

Some experts consider applied-scientific educations as a plan both for instructors and skilled experts in the field of scientific educations of agriculture for teaching the students and pupils who are interested in agricultural affairs or even employees of production units (Bannatyne and Hall, 1998). 
UNESCO (2004), in its global prospect of higher education for 21 st Century, has described the new universities as: "A place in which the entrepreneurial skills in order to facilitate the graduates' capabilities and promoting them to job producers are developed".

In another research entitled conceptual framework for the assessment of the efficiency of entrepreneurial education of programs aimed at entrepreneurship, there is a meaningful relationship between entrepreneurial education and the tendency to entrepreneurship. Knowing the fact that entrepreneurial education of programs can change the entrepreneurship purpose, which is to examine the economic relation of entrepreneurship activity, is fascinating. In this research, the first stage goal is framework development that enables us to explain the programs of entrepreneurial education alongside with the changes in visions and participants' beliefs in the program and then presents the assessment of the impact of entrepreneurial education of programs on participants' goal (Volery and Muller, 2006).

An understanding of factors influencing entrepreneurial education in Iran's applied-scientific educational centers for agriculture is crucial for creating the new opportunities for students and encouraging them to involve in entrepreneurial activity. The question is what are the factors influencing the entrepreneurial education in Iran's applied-scientific educational centers for agriculture? The purpose of this study is twofold. First, it determines the key factors that influence entrepreneurial education in Iran's appliedscientific educational centers for agriculture. Second, the study examines relationship of these factors with developing entrepreneurial education.

\section{MATERIALS AND METHODS}

Since the research aim was designing a model for entrepreneurial education system in Iran's appliedscientific educational centers for agriculture, the research in terms of nature is a kind of quantitative research and in terms of goal is applied research, in terms of controlling the variables is descriptive and correlation kind, which has been carried out in a survey way.

Table 1: Target and sample population

\begin{tabular}{lcc}
\hline Province & Total number of students & Sample \\
\hline West azarbayjan & 1114 & 85 \\
Khorasan razavi & 1491 & 114 \\
Kurdestan & 271 & 21 \\
Tehran & 906 & 69 \\
Khuzestan & 852 & 66 \\
\hline Total & 4634 & 355 \\
\hline
\end{tabular}

For examining the validity of research instrument, the views of some of the professors and experts, in centers of applied-scientific education in agriculture, were used and for examining the reliability of research instrument, 30 questionnaires were filled by students in centers of applied-scientific education in agriculture in Qazvin and Zanjan. For each part of the questionnaire Alpha Cronbach coefficient was separately calculated. Based on the results of this test and the acquired coefficient, some questions were eliminated and some others were modified. In overall the reliability or the acquired coefficient for different parts of questionnaire relating to students was more than 0.77 , so we can express that the noted coefficients are within the reliability range. Statistical population of the study consisted of 19255 students for applied-scientific education in agriculture in Iran. Based on the classification of the Ministry of Agriculture which has divided these centers into five regions, sample taking has been conducted using stratified proportionate random sampling technique. Sample size for the students is 355 people using Cochran formula. Considering the entire size of the sample, some 291 questionnaires have been returned (Table 1).

Independent variables in the study included factors (managerial, economical, social, technical and regulatory) influencing the development of entrepreneurship education in centers of appliedscientific education in agriculture. The dependent variable in this research study was the perception of students about entrepreneurship education. For measurement of correlation between the independent variables and the dependent variable correlation coefficients have been utilized and include spearman test of independence. The data were also analyzed using the technique of ordinal factor analysis.

\section{RESULTS}

The results of descriptive statistics show that the average age of students were 23.5 years old and majority of them were male (56\%). It was also reported that more than $63 \%$ of respondents were studying to earn an associate degree. Approximately 23\% of students were employed and of those employed, majority were employee of government (Table 2).

Table 2: Personal characteristics of students

\begin{tabular}{lll}
\hline Sex & Female (44\%) & Male (56\%) \\
Age year & Mean = 23.5 & \\
Degree & Associate degree (63\%) & Bachelor degree (37\%) \\
Occupation status & Employed (23\%) & Unemployed (77\%) \\
\hline
\end{tabular}


Table 3 by using the ordinal factor analysis shows the classification of the factors into five latent variables. The variables were classified into managerial, economical, social, technical and regulatory. The basic idea of factor analysis is to find a set of latent variables that contain the same information. The classic factor analysis assumes that, both observed and the latent variables are continuous variables. But, in practice, the observed variables are often ordinal.

Spearman coefficient was employed for measurement of relationships between the perception of students about entrepreneurship education and factors influencing the development of entrepreneurship education in centers of applied-scientific education in agriculture.

Table 3: Classification of factors by using ordinal factor analysis

\begin{tabular}{|c|c|c|}
\hline $\begin{array}{l}\text { Factor } \\
\text { name }\end{array}$ & Variables & $\begin{array}{l}\text { Variance by } \\
\text { factor }(\%)\end{array}$ \\
\hline Social & $\begin{array}{l}\text { Beliefs about entrepreneurial education } \\
\text { Attitudes about entrepreneurial education } \\
\text { Social status of family, } \\
\text { Negative attitude about entrepreneurship, } \\
\text { Lack of social interaction } \\
\text { Family's educational level }\end{array}$ & 21.19 \\
\hline Economical & $\begin{array}{l}\text { Securing the cost of entrepreneurial practical } \\
\text { training, } \\
\text { Allocating budget to hire instructors, } \\
\text { Providing financial resources for } \\
\text { entrepreneurial education } \\
\text { Providing grants to do research about } \\
\text { entrepreneurship } \\
\text { Organizing the financial mechanisms } \\
\text { for centers }\end{array}$ & 12.46 \\
\hline Managerial & $\begin{array}{l}\text { Participation of managers of centers in } \\
\text { educational program, } \\
\text { Changing the knowledge level of managers } \\
\text { about entrepreneurship education, } \\
\text { Changing the attitudes of managers about } \\
\text { entrepreneurial education }\end{array}$ & 9.10 \\
\hline Technical & $\begin{array}{l}\text { Access to educational hard wares and soft } \\
\text { wares, } \\
\text { Access to technology and know how required } \\
\text { For entrepreneurship education, } \\
\text { Availability of equipments for practical } \\
\text { training }\end{array}$ & 8.73 \\
\hline Regulatory & $\begin{array}{l}\text { Tax exemption for entrepreneurship } \\
\text { companies established by entrepreneurs } \\
\text { graduates, } \\
\text { Facilitating the registration of } \\
\text { entrepreneurship companies, } \\
\text { Stimulus packages by governments for } \\
\text { entrepreneurs graduates }\end{array}$ & 7.12 \\
\hline
\end{tabular}

Table 4: Correlation measures between independent variables and dependent variable

\begin{tabular}{llll}
\hline Independent variables & Dependent variable & $\mathrm{R}$ & Sig. \\
\hline Economical factors & Entrepreneurial education & 0.338 & $0.000^{* *}$ \\
Social factors & Entrepreneurial education & 0.156 & $0.013^{*}$ \\
Technical factors & Entrepreneurial education & 0.235 & $0.000^{* *}$ \\
Managerial factors & Entrepreneurial education & 0.253 & $0.000^{* *}$ \\
Regulatory factors & Entrepreneurial education & 0.265 & $0.000^{* *}$ \\
\hline$* *: \mathrm{p}<0.01 ; *$ p $<0.05$ & & &
\end{tabular}

Table 4 shows that there was relationship between economical, social, technical, regulatory and managerial factors and perception of students about entrepreneurial education.

\section{DISCUSSION}

As the ordinal factor analysis showed, the factors were categorized into five groups, namely social, economical, managerial, technical and regulatory, ordered by the magnitude of their impact (Fig. 1).

The findings reflect an important fact, namely that entrepreneurship would have a positive impact on perception of students about entrepreneurial education. In this regard, a sound regulatory and policy environment is a necessary prerequisite for enhancing the capacity of students to start entrepreneurship activity. This has been pointed out by several authors including (Pages and Markley, 2004; Smit, 2004).

The results of the study also point to the relationship between social factors and development of entrepreneurial education, a finding in accordance with the findings of the studies by (Dodd and Gotsis, 2007; Pages and Markley, 2004).

The findings about economical factors are in accordance with those of (Mirzaee, 2002; Volery and Muller, 2006) which show that allocating the necessary budgets and securing the cost of practical training would have affect on the entrepreneurial education.

Regarding the nature of agricultural appliedscientific educations which has been planned and executed to teach and train skilled and specialist manpower, increasing their technical and scientific ability to obtain job vacancies and create a new business or job (entrepreneurship), coordinating and conformity of these educations with the requirements of production sectors, service sectors, employment and

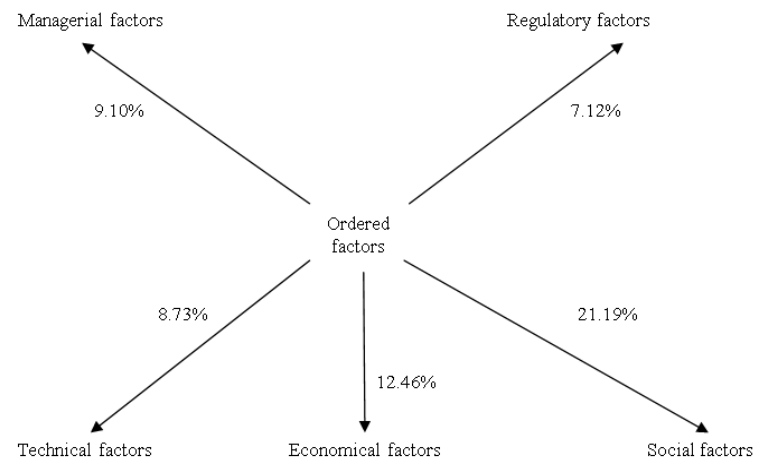

Fig. 1: Classification of challenges by using ordinal factor analysis 
labor market system and in parallel regulating the syllabuses of courses, conformity of schedule content and education methods with entrepreneurship perspective, promoting self-confidence and selfassurance mentality and motivating students to be entrepreneurs are among the measures which can be effective on promoting agricultural education, increasing human resources productivity in agriculture sector and social capabilities and self-employment of graduates of the universities.

\section{CONCLUSION}

Entrepreneurial education has a tremendous potential to help in the employment status of students in Iran's applied-scientific educational centers for agriculture. These centers have the opportunity to play a major role in the development of entrepreneurial education.

The development of entrepreneurial education results in creating more jobs and employment sustainability could be achieved over time. Therefore, certain special factors in developing entrepreneurial education among students in these centers should be identified and need to be carefully examined.

Innovative strategies need to be developed that cater specifically the entrepreneurship educational needs of students. Applied-scientific educational centers for agriculture in Iran need to provide practical training in entrepreneurship to their students, to make them more aware of the benefits of entrepreneurship and to address the factors that impact on developing entrepreneurial education in the centers.

\section{REFERENCES}

Audretsch, D.B., 2002. Entrepreneurship: A survey of the literature. Institute for development strategies, Indiana University and centre for economic policy research CEPR, London.

Bannatyne, M.W.M. and R.A. Hall, 1998. Technology and vocational educational reform in the Russian federation. J. Technol. Stud., 24: 31-37. http://www.eric.ed.gov/ERICWebPortal/custom/po rtlets/recordDetails/detailmini.jsp?_nfpb=true\&_\& ERICExtSearch_SearchValue_0=EJ574865\&ERIC ExtSearch_SearchType_0=no\&accno=EJ574865

ERIC., 2001. Australian vocational education and training statistics, 2001: Financial data. http://www.eric.ed.gov/ERICWebPortal/custom/po rtlets/recordDetails/detailmini.jsp?_nfpb=true\&_\& ERICExtSearch_SearchValue_0=ED469710\&ERI CExtSearch_SearchType_0=no\&accno=ED469710
Dodd, S.D. and G. Gotsis, 2007. http://www.ingentaconnect.com/content/ip/ije/2007 /00000008/00000002/art00001. Int. J. Entrepren. Innov., 8: 93-104.

Fayzabadi, R. and G.H. Khoynejad, 2002. Higher education of applied-scientific in terms of occupation (Case Study: Khorasan Complex of Agricultural Education), the articles of the third national congress on applied-scientific educations, Tehran, Nov-Dec., 2002.

Hajimirrahimi, S.D., 1999. Analytical examination of agricultural applied-scientific educations and approaches for the development of this education from the views of teachers, managers and authorities of agricultural education centers. Proceeding of the Collection of Articles of 2nd Conference on of Examination and Analysis of Applied-Scientific Educations, Nov. 1999, Applied-Scientific Educational Center of Agriculture Ministry Publication, Tehran, pp: 198210.

Heydari, H., 2002. Examining the admission conditions of students of applied-scientific courses of agriculture ministry in 2002. Proceeding of the Collection of Articles of the 5th Applied-Scientific Education Conference of Agricultural Section, Apr.-May 2002, Applied-Scientific Educational Center of Agriculture Ministry Publication, Shiraz, pp: 253-268.

Higgins, M. and J. Morgan, 2000. The role of creativity in planning: The creative practitioner. Plann. Pract. Res., $\quad 15$ : 117-128. http://www.centreforinnovations.com/researchLib/ Role\%20of\%20creativity\%20in\%20planning.pdf

Institute of Applied-Scientific Educations, 2002. Higher applied-scientific Educations in the Ministry of Agriculture, aims, necessities, programs and Report of agricultural researches and education organization's activities. Vol. 8, pp: 207-217.

Kuratko, D.F., 2003. Entrepreneurship education: Emerging trends and challenges for the 21st Century. Coleman White paper Series. www.usasbe.org/pdf/CWP-2003- Kuratko.pdf/

Landkinen, T., 2000. The second international congress on technical and vocational education. www.unesco.org/congress/pdf/landkinen.pdf

Lankard, B.A., 1994. Employer's expectations of vocational education. http://www.ericdigests.org/1995-2/vocational.htm McElwee, G., 2005. Developing entrepreneurial skills of farmers. University of Lincoln. http://www.esofarmers.org/ 
Mirzaee, A., 2002. Examining the occupational conditions of the graduates of higher education of agricultural applied scientific courses. Master Degree Thesis, Department of Educational Management, Khorasan Province Management and Planning Organization.

Nelson, R.E., 1986. The Promotion of Small Enterprise Development. In: Country Studies: Entrepreneurship and Self-Employment Training, Nelson, R.E. (Ed.). Asian Development Bank, Manila, The Philippines, pp: 192.

Nouroozzadeh, R. and M. Mehrabiyeganeh, 2006. Higher applied-scientific education centers of agriculture with the emphasis on agricultural sector. Vol. 1, pp: 78-91.

Pages, E.R. and D.M. Markley, 2004. Understanding the environment for rural North Carolina. Center for Rural Entrepreneurship. http: Ilwww.ruraleship.org

Sherief, S.R., 2005. Entrepreneurship as an economics force in rural development. http://www.africaeconomicanalysis.org/articles/gen /rural_entrepreneurship.html

Smit, A.B., 2004. Changing external conditions require high levels of entrepreneurship in agriculture, Proceedings of the 15th International Symposium on Horticultural Economics and Management, Sept. 2004, International Society for Horticultural Science Publication, Berlin, Germany, pp: 167-173.

Streeter, D.H. J.P. Jaquette, Jr., and K. Hovis, 2002. University-wide entrepreneurship education: Alternative models and current trends. http://epe.cornell.edu/downloads/WP_2002_final.P $\mathrm{DF}$

The Agriculture and Natural Resources Engineering System Organization, 2007. Organizing of agricultural and natural resources graduates' employment. Vol. 5, pp: 32-42.
UNESCO., 1997. Higher education: The consequences of change for graduate employment. Proceedings of the 5th UNESCO-NGO Collective Consultation on Higher Education, Feb. 10-12, Paris, pp: 63-78.

UNESCO., 2004. Higher education in Europe. http://www.unesdoc.unesco.org/images/001621/16 2192e.pdf

Ussman, A.M., 1998. University and entrepreneurship development. Academy of Business and Administrative Science (ABAS). http://www.sba.muohio.edu/abas/1998/hungria.ing. pdf

Varma, P., 2000. Technical and vocational education and development. Development Express, Canadian International Development Agency.

Volery, T. and S. Muller, 2006. Conceptual framework for testing the effectiveness of entrepreneurship education programs towards entrepreneurial intention. http://www.kmu.unisg.ch/rencontres/RENC 2006/band 2006.html

Zamani, G.H., 2001. The estimate of the needed specialized manpower and job pathology of agricultural graduates. The Higher Education Planning and Research Institute of Ministry of Science, Researches and Technology, Vol. 12, pp: 362-371.

Zoltan, A.C., 2006. How is entrepreneurship good for economic growth? http://mitpress.mit.edu/journal/pdf/INNOV0101_p o97-107_02-23-06.pdf 